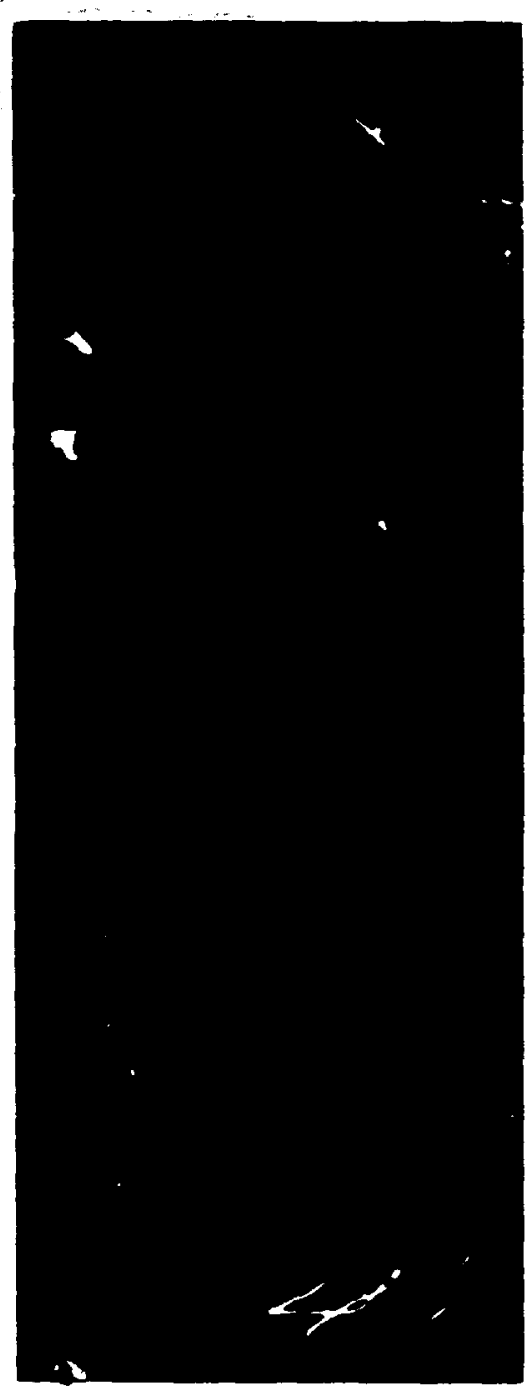

\title{
Summary of ORNL Investigation of In-Core Vibrations in BWR-4s
}

\author{
D. N. Fry \\ R. C. Kryter \\ M. V. Mathis \\ J. E. Mott \\ J. C. Robinson
}
Prepared for the U.S. Nuclear Regulatory Commission Office of Nuclear Reactor Regulation Under Interagency Agreement ERDA 40-544-75
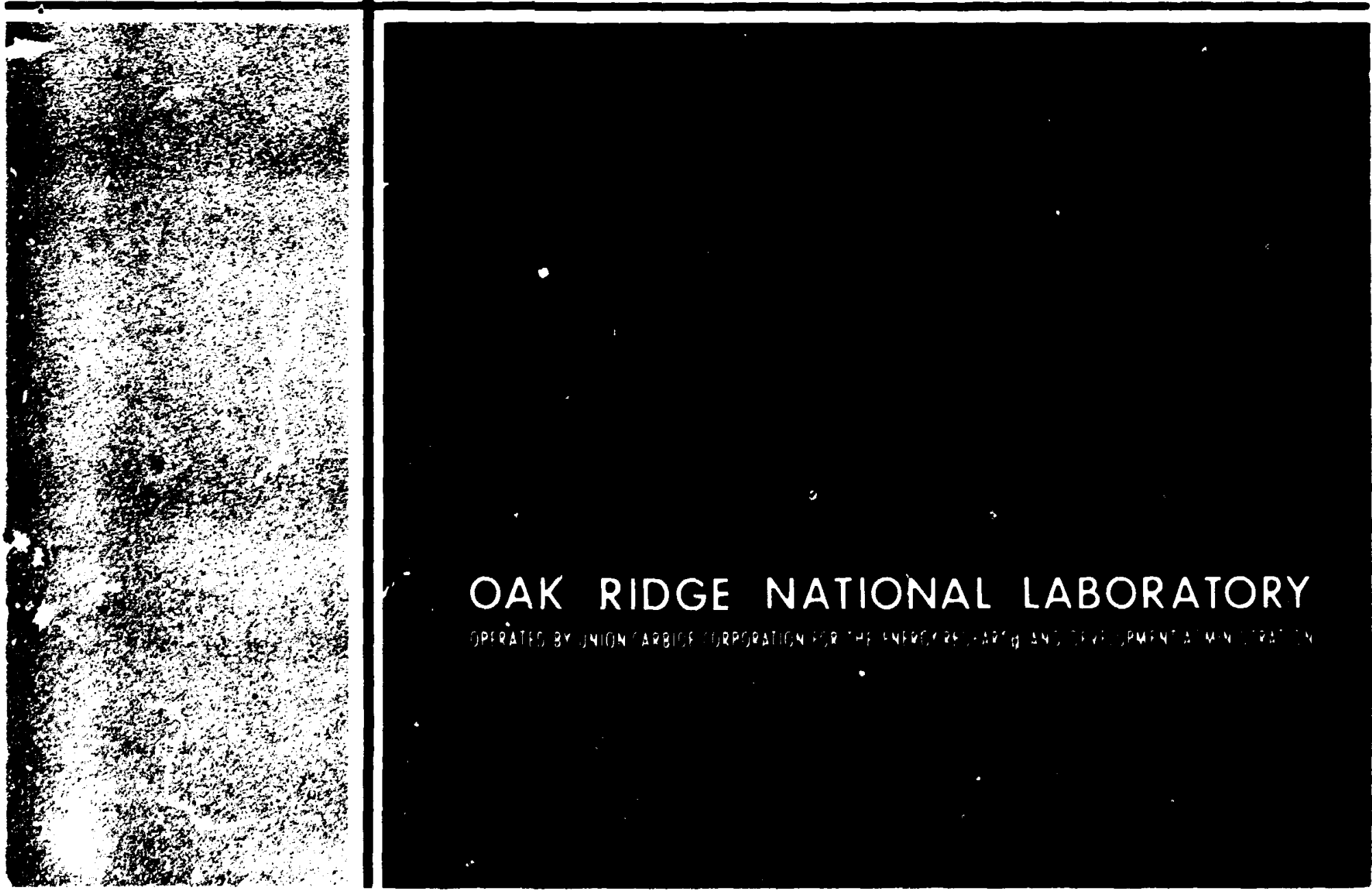


\title{
Printed in the United States of America. Available trom National Technical Information Service \\ U.S. Department of Commerce
}

5285 Port Royal Road. Springfield. Virginia 22161

Price: Printed Copy \$4.00; Microfiche $\$ 3.00$

\begin{abstract}
This report was prepared as an account of work spcnsored by the United States Government Nerther the United States nor the Energy Research and Development Mdministration United States Nuclear Pegulatory Commission. no- any of their employees. nor any of their contractors. subcontractors. Of their employees trathes any warranty. express or implied. or assumes ary legal liability or responsib livy for me accuracy. completerness or usefulness of any information. apcaratus product or process disclosed. or represents that its use would not in ${ }^{2}$ inge privately owned pigh is
\end{abstract}


Contract Ho. W-740S-eng-26

INSTRURETTATIOA AND CONTEOLS DIVISIOA

SURARY OF ORen IMVESTIGATIOA OF IH-CONE VIBRATIONS IN BinR-48

D. A. Fry, R. C. Xryter, M. V. Mrthts J. E. Hott* and J. C. Robinson*

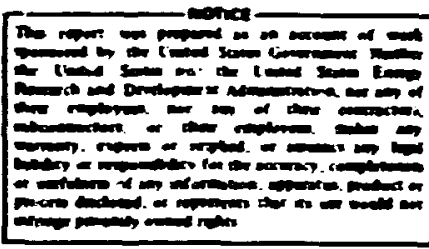

Manuscript Completed - March 25, 1977

Date Published - May 1977

\footnotetext{
Consultant, Department of Nuclear Engineering, the University of Tennessee, Rnoxville.
}

\author{
Prepared for the \\ U.S. Nuclear Regulacory Comission \\ Office of Nuclear Reactor Regulation \\ Under Interagency Agreement EDOA 40-544-75
}

Prepared by the

OAK RIDGE MATIOANL LABORATORY

Oak R1dge, Tennessee 37830

operated by

Inton Carbide Corporation

for the

EIERGY RESEARCH AMD DEVELOPIENT ADFINISTRATION

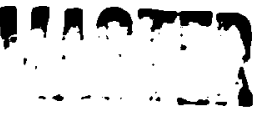




\section{ACKMOULEDGENTS}

The Investigation sumarized in this report extended over core than a year and could not have been colpleted without the cooperation and contributions of may individuals. In particular, the operating staff at the plants where we ade tests were very cooperative and helpful in assisting with the measurements. We wish to acknowledge and thank the Ceneral Electric Company for the personnel and equipment it provided for the in-core inpact tests.

We are also grateful for the valuable assistance in measurements and data analysis provided by several graduate students of the Nuclear Engineering Department, The University of Tennessee, Knoxville, and by the staff of the development section of the Instrumentation and Controls Division of ORnL.

We are deeply indebted to J. T. Snith of the University of Tennessee and to 0 . C. Cole of ORIL for their expert assistance in perforaing the Easurements throughout this investigation. 
ABSTRACT

This report describes the use of noise analysis to investigate incore instrument tube vibrations in Ew-4 reactors. Heutron noise signals from in-core fission chabers and acoustic noise signals fron externally mounted accelerometers were used in these studies. The results show that neutron noise can be used to detect vibration and, more importantly, Ipacting of Instrument tubes against adjacent fut: channel bozes. Externaliy wouted acceleroneters detect impacting but not rubbing of instrument tubes against fuel channel boxes. Accelerometers can montor imacting only on the particular instrument tube where the accelerometer is nounted. Surveillance for instrument tube impacts can be accouplished using standard BUR-4 in-core power range neutron flux detectors at all instrument tube locations containing these detectors. Ex-vessel accelerometers can then be used to mritor Instrument tubes that lack power range neutron flux detectors. However, noise on axial flux profiles obtained with wovable in-core detectors is not a rellable indicator of imacting, because the recorder used to plot the flux profiles does not respond adequately to the noise frequency generated by ilpacting. 
$\mathbf{v 1 1}$

contrans

Page

1. IITEODUCTIOAN ..................... 1

2. Im-CORE IYPACT TESTS .................. 3

3. I -CORE NEUTRON NOISE VS EX-VESSEL ACCELEROAITER SIGWLS - - 11

4. USE OF TIP TRACES FOR MAPACT MONITORING . . . . . . . . 15

5. EFTECT OF bTPASS hOLE PLUGGING ON VIBRATIONS $\ldots . \ldots$

6. COEPARISON OF BOISE SIGATURES WITH VISUAL IASPECTION OF FUEL BOXES .................... 21

7. COACLUSTONS AND RECOARERDATIONS ............. 23

8. REFERENCES .......................... 25 


\section{INTRODUCTION}

This report sumarizes the results of our investigation of in-core instrument tube vibrations in BWR-4s. The objectives of this investigation were to: (1) deternine if acoustic nolse from acceleroneters munted outside the reactor vessel can be used to detect and quantify impacting of instrument tubes against fuel channel boxes, (2) deteraine If neutron noise from fixed in-core detectors can be used to detect impacting of instrument tubes against fuel channel boxes, (3) deternine if neutron noise from in-core detectors can be used to assess the degree of wear of fuel channel boxes caused by instrument tube Impacts, and (4) deteraine the degree to which instrument tube vibrations are recuced by plugging the bypass cooling holes in the core support plate.

BUR-48 have in-core instrunent tubes (thin walled and inconstrained through the core region) that house neutron detectors or neutron sources. To improve cooling in the vicinity of an instrument tube, from 0 to 4 holes (as needed) have been drilled through the lower core support plate near each instrument tube penetration. While improving the cooling, these coolant bypass holes apparently also create a cross flow that induces vibrations in the instrument tubes of sufficient aplitude that sore of the instrument tubes contact the comers of adjacent fuel channel boxes with sufficient force and rapidity to cause excessive wear of the boxes.

To accomplish the preceding objectives, we measur ad the acoustic noise with out-of-vessel accelerometers and the neutron noise with fixed, in-core detectors at several BHR-4s. The specific BWR-4 plants are not 
Identified in this report because they are nominally of the same design, and we assure that the differences such as core size and instrument tube dianeter (some plants have 0.70-in.-dian tubes and others 0.75-in.) do not significantly affect the noise signatures obtained. Evidence to support this assuption is presented in Sect. 3, where signatures from three plants are compared.

During a refueling shutdown at a BHR-4, we perfored a test to deternine the sensitivity of ex-vessel accelerometers to rapping on an in-core instrume tube. This experiment and its results are described in Sect. 2.

Ex-vessel accelerometer signals and in-core neutron noise fron an operating BWR-4 were compared to deternine if neutron noise can be used to detect impacting in lieu of wunting accelerometers on 2.11 instrument tubes (Sect. 3).

We analyzed neutron noise signatures from the BURs to conpare the shape and magnitude of nolse spectra as a function of flow rate and to assess the change in the noise signatures after the bypass cooling holes in the core support plate were plugged. These results are described in Sect. 5 .

The utflities and the General Electric Company (GE) visually inspected the fuel channel boxes at several BURs. During these Inspections, the channel box wear was measured optically, and the boxes werc rejected or reused based on criterla established by GE. We cospared these neasurewents with neutron nolse signatures obtained prior to shutdown (see Sect. 6) to deternd ne to what degree neutron noise correlates with wear of channel boxes. 


\section{IN-CORE LPACT TESTS}

Realizing that we lacked a yuantitative understanding of the relationships between manical contacts anong instrumer: tubes and fuel channel boxes within the core and acoustic energy sensed at ex-core locat fons, we proposed special tests werein ex-core accelerometer responses to in-core Impacts of knom magnitude would be recorded, thereby establishing a spaceand (perhaps) anplitude-dependent transfer function. Access to the core internals naturally presented a problea, but fortuitously a Bh-4 in a defueled state for other reasons was ade available for these special tests, which were carried out jointly by the utility, GE, and 0arh personnel.

The priary objective of these tests was to define the detection sensitivity of ex-core accelerometers to stulated metal-on-wetal impacting or rubbing at selected axial positions along the surface of the instrument tubes. The secondary objective was to comare the detection sensitivities of accelerometers already in use at two ez-core locations at affected BuR plants (labeled "Flange Acreleroweter" and "IIP accelerometer and Cable Clamp" in Fig. 1, which are $223 \mathrm{ft}$ and $\sim 110 \mathrm{ft}$ from the

fuel centerline, respectively). Specifically, we sought answers to the following questions:

1. How light an imact can be detected rellably in the presence of normal plant background notses?

2. Is detection sensitivity dependent upon axial location of metal-onmetal impacting or rubbing? 


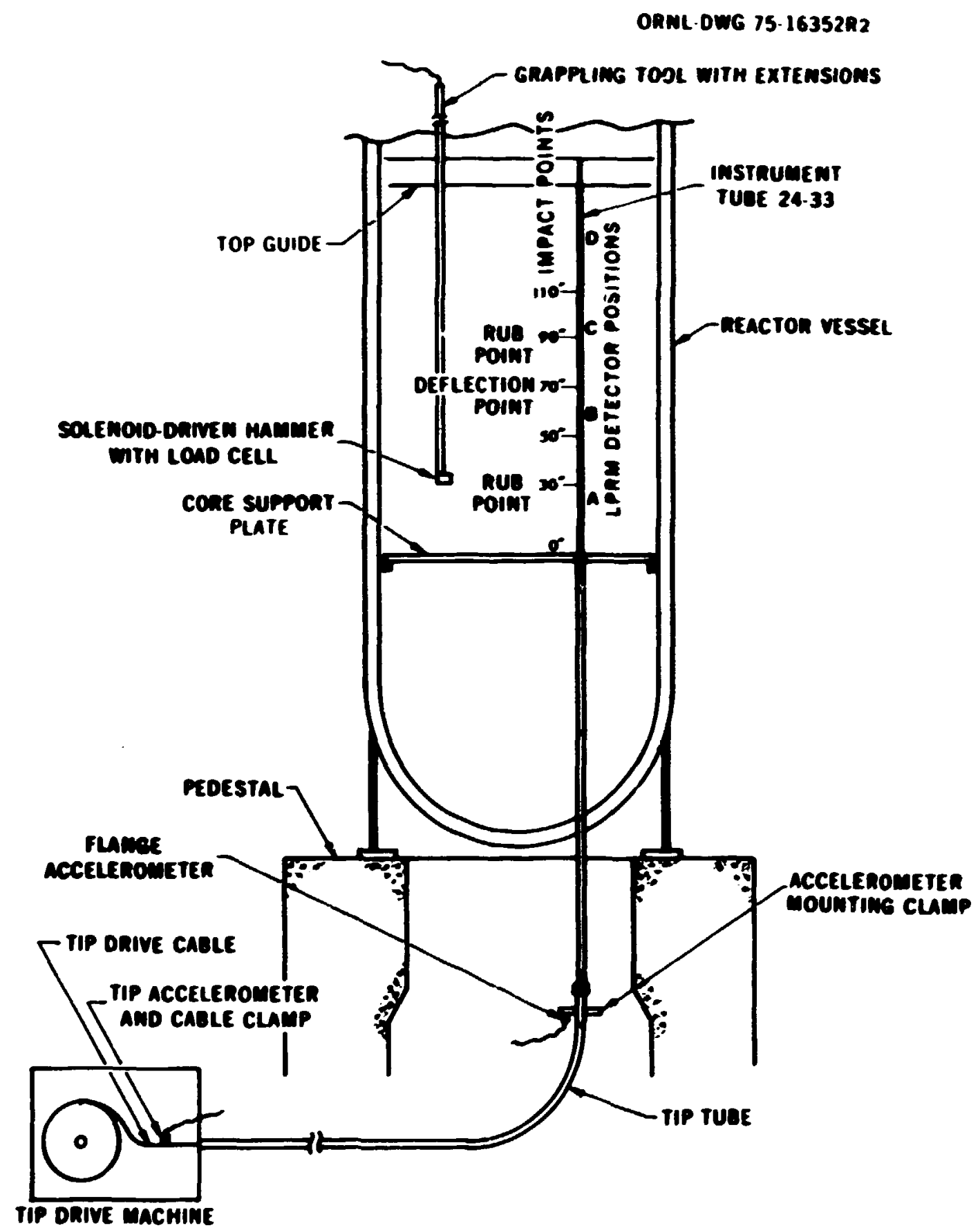

F18. 1. In-core Impact test instrumentation and axial teat positions. (A, B, C, and D indicate the locations of Local Power Range Monitor detectors.) 
3. Is the character of the detected noise due to rubbing different from that due to impact ing?

4. Is crosstalk within the reactor internals structure appreciable, 1.e., can impacts on a given instrument tube be detected with an accelerometer attached to an adjacent tube? Is control blade ratting a significant source of cometing noise?

5. Can characteristics of the detected noise pulses (amplitude, oscillation count, etc.) be simply related to the impact force (or energy) so that the flange-wounted acceleroneter syste wight be cal ibrated in terns of the input?

6. Is there a decided advantage in either the flange or the TIP mach ine mounting position for accelerometers?

Figure I is an elevation viex of the reactor vessel and its supportIng pedestal, an in-core Instrument tube with its TIP tube lead'ng to the TIP drive machine outside the primary containent, the two accelerometer wounting positions, and the grappling tool that was manipulated by personnel to simulate ipacting and rubbing of the instrument tube and other in-core structures. Figure 2 is a plan view of the relative radial locations of the instrusented sube position (24-33) that was directly impacted or rubbed, and the control blade (position 26-31) and adfacent tube (positIon 32-33) that were also Impacted to assess the degree to which acoustic energy thus generated is transaticed to the instrumented tube. Figures 1 and 2 are not intended to show the actual state of core disassembly; in fact, all fuel charnel boxes were rewoved at the the of the tests, but 
ORML DWG 76.17309

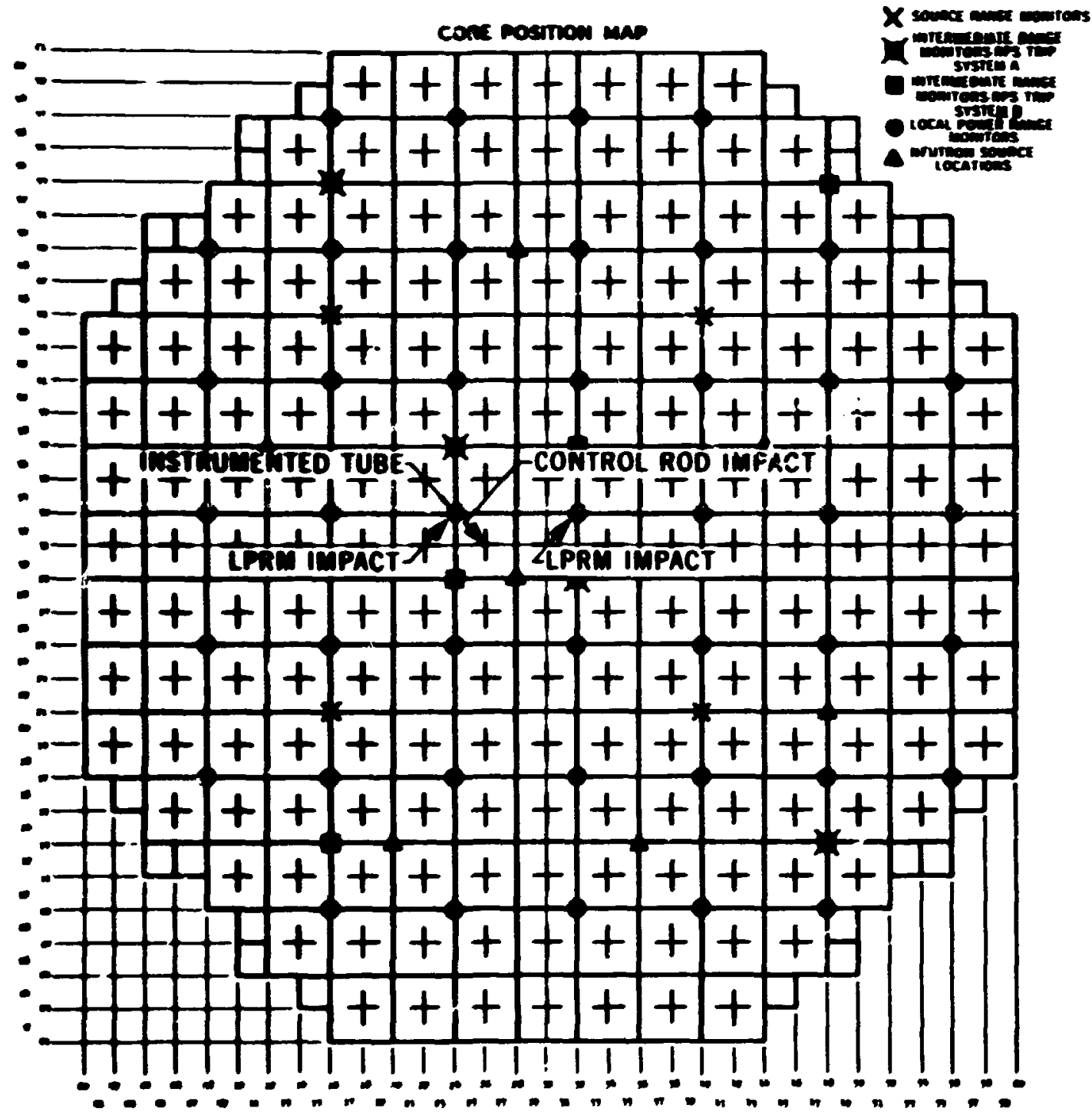

Fig. 2. Radial test positions for in-core Impact tests. 
cost instrument tubes (indicated in Fig. 2 by X's, filled squares, filled circles, and $X$-ed squares) and some control blades (Indicated by crosses) were instailed.

Figure 1 also shows the axial positions where instrumert tube 24-33 was impacted and rubbed and the relation of these positions to the locations of the LPRM detectors A, R, C, and D. In the original test plan, the Impacting device (a solenoid-driven hamer with a load cell, Fig. 1) was to have given both reproduc ible and callbrated results (in teras of momentum transferted to the impacted object). Hovever, the load cell which operated as expected in air prior to insertion in the reactor pool failed to do so when imersed in water in the reactor. Therefore, the Impacting hamer was used, but the load cell was not used for the cest3.

Typical accelerometer resporses to impacts at various axial positions are shown in Fig. 3. The ordinates are $g$ values sensed at the accelerometer positions $\left(g=32.2 \mathrm{ft} / \mathrm{sec}^{2}\right.$, or $\left.9.81 \mathrm{~m} / \mathrm{sec}^{2}\right)$, but th must be stressed that these values are not directly translatable to accelerations imparted to the instrument tube at the impacted point. All plots cover a time span of $12.5 \mathrm{msec}$, but the abscissa origins, $t=0$, are displaced arbitrarily relative to the inftiating impact; so the initial sound arrival times are not to be compared among the three plot pairs. Conclusions drawn from $\because \$ g$. 3 are that (1) instrument tube Impacts by the solenoid-driven hamer are reailly detectable above the background noise, with an $S / N$ ratio $>10$ at the $t$ lange mounting position; (2) the $S / N$ ratio and the general character of the alange accelerometer signal are essentially independent of the axial posttion of the impact; and (3) these same impacts ate not detected above background by identical accelerometers mounted at the TIP drive machine. 
Before suggesting universal applicability of these conclusions, we ast assess the realisa of the test conditions, 1.e., the S/N ratio (which affects the probability that an event will be detected) obviously depends both on the level of background noise and on the force of the impact imparted to the instrument tube. Oring to the lack of meaningful results fron the load cell, we have no quantitative measurement of the latter. However, other information suggests that the conditions vere realistic: the actual flow-induced instrument tube vibrations at an operating BWR-4 produced accelerations at the flange counting position of 0.5-12 8 peakto-peak (Fig. 3 shows typically $1.5-3$ g p-p), while the operating plant background was 60.1 g P-p (Fig. 3 shows 0.2 g p-p). Hence, the S/N ratko for our tests was roughly the same or slightly poorer than ind been observed during actual dreactor operation; this implies that conclusions regarding detectability dram from the in-core imact tests vill probably not be overly optimistic in practice.

A typtcal flange-mounted acceleroneter response to five rubbing contacts, each $20.6 \mathrm{sec}$ duration, of Instruasent tube 24-33 with the grappling tool over a 20-ser incerval is shown in Fig. 4. The upper, square-pulse trace is a marker signal that indicates the intervals during which rubbing took place (output level $=0 \mathrm{~V}$ ) versus the quiescent intervals (output level $=1 \mathrm{v})$. Since there are no discemible differences in the accelerometer signal characteristics during the two intervals, we conclude that rubbing sounds of the (unknown) magnitude that we were able to

\footnotetext{
* We have no explanation for this last discrepancy except that extensive, nolse-producing maintenance work was belng carried out in the test area at the shutdown plant.
} 

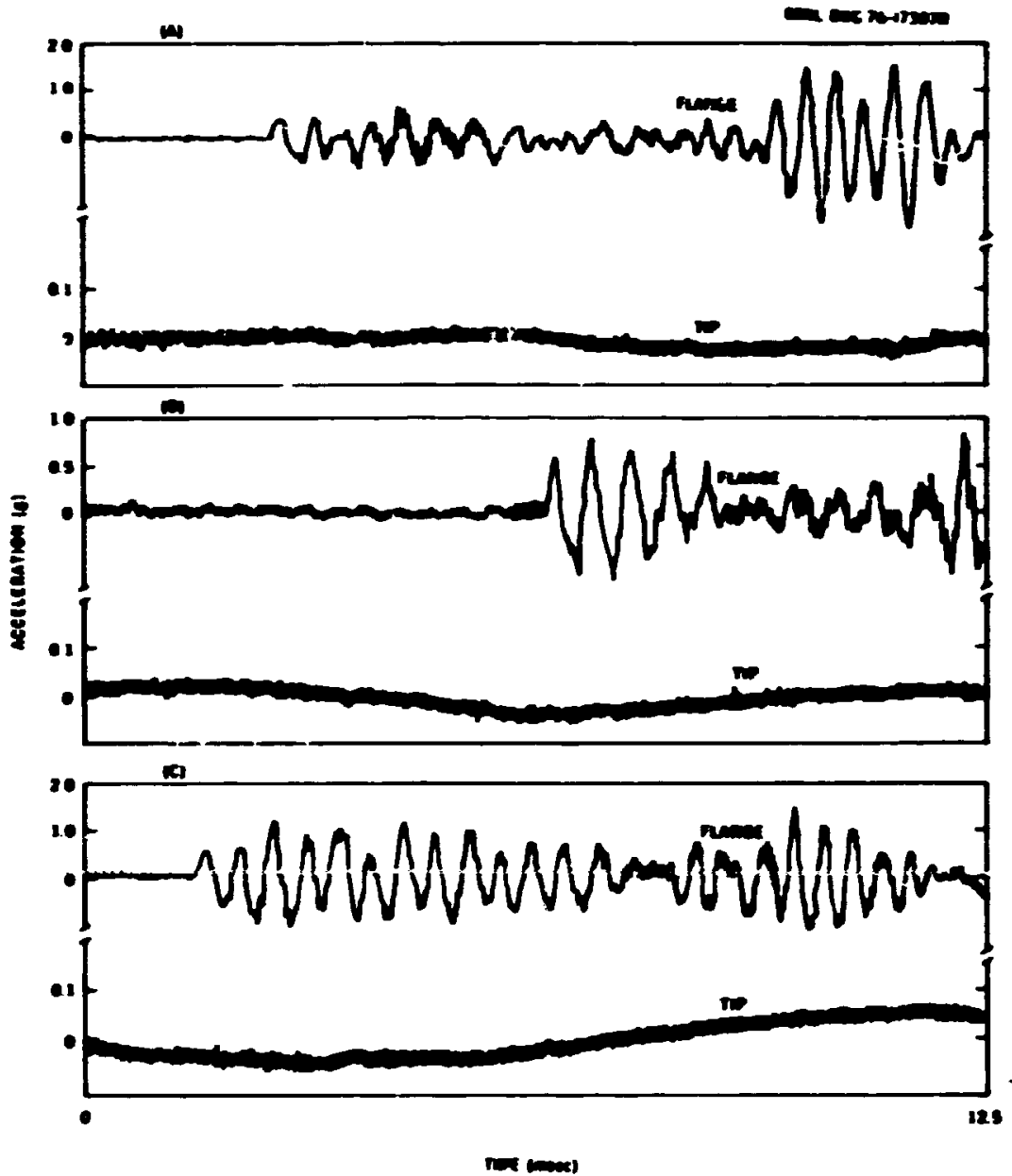

F18. 3. Response of flange and TIP machine accelerometers to Inpacts at (A) $70 \mathrm{In}$., (E) $90 \mathrm{in}$,, and (C) $110 \mathrm{in}$. fron the core support plate.

and ans $76-17306$

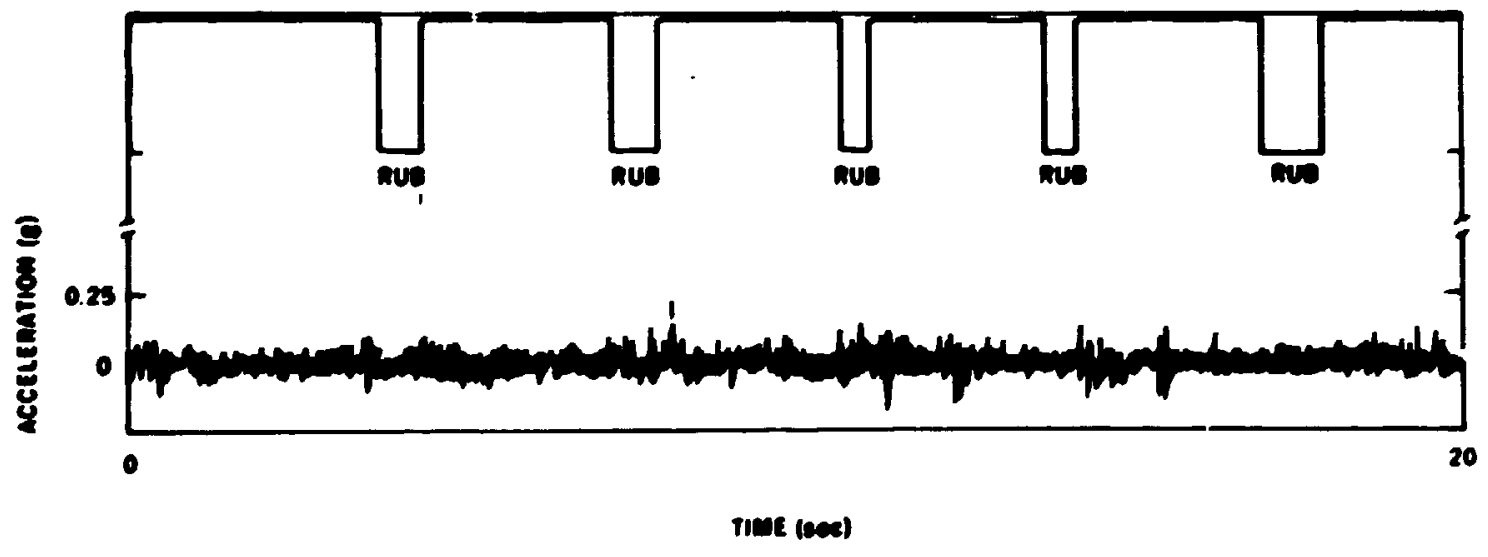

F18. 4. Response of flange accelerometer to rubbing at $90 \mathrm{in}$. from core support plate. 
produce vith a grappling tool would be undetectable in the presence of nornal reactor background noise by accelerometers nounted outside the reactor pressure ressel.

Other tests were perforned in an at tempt to answer the questions posed previously. Since the signal waveforms obtained did not differ substantially from the figures already shown, we serely suarize our over-all coaclustons below without presentation of additional data:

1. Instrument tube inpacts of suffictent force to produce accelerations of a few 8 at the flange wouting position vere readily detectable $(S / I=10)$, but these impacts were not detected at the IIP drive achine location. By corparing acceleration levels at the flange location In an operating reactor where ilpacting was occurring with the signals from our in-core tests, we conclude that ipacts of the level. we Introduced could be detected at the flange location in the presence of operating reactor background noise.

2. Oring to the lack of eaningful results fron the $103 d$ cell on the imacting hamer, no absolute calibration of the imacting force required to produce a 18 acceleration at the flange position was obtained. However, from tests perforned both in air and in water at GE, using a sinilar impacting hamer and load cell, the maximun iapact force was est 1mated to be 6-15 $1 \mathrm{~b}$.

3. Impact detection sensitivity at the flarge wounting position was found to be essentially independent of the impact position along the Instrument tube. 
4. Rubbing of the Instrunt tube could not be detected relinbly above background noise at elther sensor location.

5. Crosstalk within the reactor internals structure was deternined to be ineasurably small, i.e., flange mounted accelerometers responded only to impacts delivered directly to the instrument tube on which they were attached, but they were completely Insensit Ive to Inpacts on adjacent instrument tubes or control rods.

6. Characteristics of the detected sound pulses fron the acceleroneters were not found to be simply related to the impact force or energy, 1.e., no "transfer function" for acoustic energy propagation was developed.

\section{IN-CORE REUTRON LOISE vS EX-VESSEL ACCELEBOATER SIGULS}

As stated previously, BWR-4s have a large nuber of in-core fission chabers that are used to nonitcr local neutron flux. Measurements were ade in an operating BWR-4 to rapare signals fron in-core detectors with signals from ex-vessel accelerometers to deternine if in-core neutron noise could be used to detect iffacting of the guide tubes against fuel channel boxes. We concluded from previous studies in another BWR-4 (Sect. 2) that acceleroneters mounted on the guide tube flange just below the reactor vessel detect ifpacting (but not rubbing) reliably.

Neutron nolse analysis of signa:s fro in-core fission detectors has been demonstrated to detect vibration of instrument tubes.1 The normalized power spectral density (IPSD) has a clearly defined resonance at $2.5 \mathrm{~Hz}$ (presuably the tube's fundanental frequency). Howtever, 
atte-pts to correlate the manitude of this resonance with channel box wear were unsuccessful, and ve concluded that the angnitude of this vibrational wode is not necessarily related to fmacting. This is plaustble because the tube may have a mch larger (but noncontacting) displacenent in a direction parallel to the channel box wall than in the perpendicular direction. Therefore, another wethod of detecting ippactIng is required.

We postulated that the agnitude of the normal ized cross-power spectral density (NCPSD) of the upper two LPTEI detectors (C and D) in the Instrument tube (see Figs. 1 and 2 for axial and radial detector locations) at a frequency between 24 and $6 \mathrm{~Hz}$ (the exact frequency is indicated by a maximu in tive coinerence) wight be an Indicator of impsceing. This appears physically reasonable fo: two reasons: (1) impacting, a nonlinear phenonenon, causes an upward shift in resonant frequency, and hence a resonance in the 4-6 Hz range rather than at the cube's fundanental frequency; and (2) the calculated natural frequency of the fuel channel box is $25 \mathrm{~Hz}$. Therefore, whenever imacting occurs, the channel box also vibrates. Its witon is sinflar to a cantilevered bean attached to the lower core support plate, with the largest anplitude in the upper region of the core. This cotion should cause perturbations in the neutron flux that are coherent along the tube axis.

The above postulate was verified by comparing the XCPSD in the noninal 4-6 Hz range with results from accelercmeters mounted on the instrument tube flange imediately below the pressure vessel (see Fig. 1). The

\footnotetext{
*The agnitude of CPSD was normalized by dividing by the product of the steady-state signal levels (see ref. 2 for a more complete explanation of neutron noise signal analysis).
} 
abllity of the accelerometers to detec: inpacting was established as described in Sect. 2. Spectra vere obtained for a nuber of core flow rates ranging from 50 to 902 of full-rated flow. P1gure 5 shows the flow dependence of MCPSD. Note that the resonance in the 1-3 $\mathrm{Hz}$ frequency range does not disappear at $50 \mathrm{z}$ flow. However, the broader resonance in the vicinity of $5 \mathrm{~Hz}$ dininishes as the flow is reduced. We belleve that this peak is caused by lpacting of the instrument tube against fuel boxes; therefore, ve compared its aplitude with acceleroneter signals.

Figure 6 presents the magnitude of the NCPSD at the frequency of aximu coherence (in the 4-6 Hz range) as a function of flow; also displayed is the threshold flow above which impacting, as deternined by the accelerometers, was in evidence. The values of MCPSD at the onset of impacting lie in a range from $(1.5$ to 3.0$) \times 10^{-6} \mathrm{~Hz}^{-1}$. For the two tubes where inpacting was never detected by acceleroneters, the MCPSD remained below $10^{-6} \mathrm{~Hz}^{-1}$ for a]' flows (see F1g. 6).

We therefore conclude that impacting of instrunent tubes against fuel boxes in BWR-4s can be detected by noise analysis of the signals from the in-core fission detectors presently installed. When the agantude of the ICPSD between the upper two detectors exceeds $2_{2} \times 10^{-6} \mathrm{~Hz}^{-1}$ In the vicinity of $5 \mathrm{~Hz}$, impacting is probably occurring. If impacting is detected by neutron noise, additional diagnostic information (such as accelerometer measurements) could be used to confin the diagnosis.

A prerequisite for universal applitcation of the criterion for inpacting stated in the preceding paragraph is that normal background neutron noise wust be sidlar in all BUR-4 plants. Therefore, we performed 


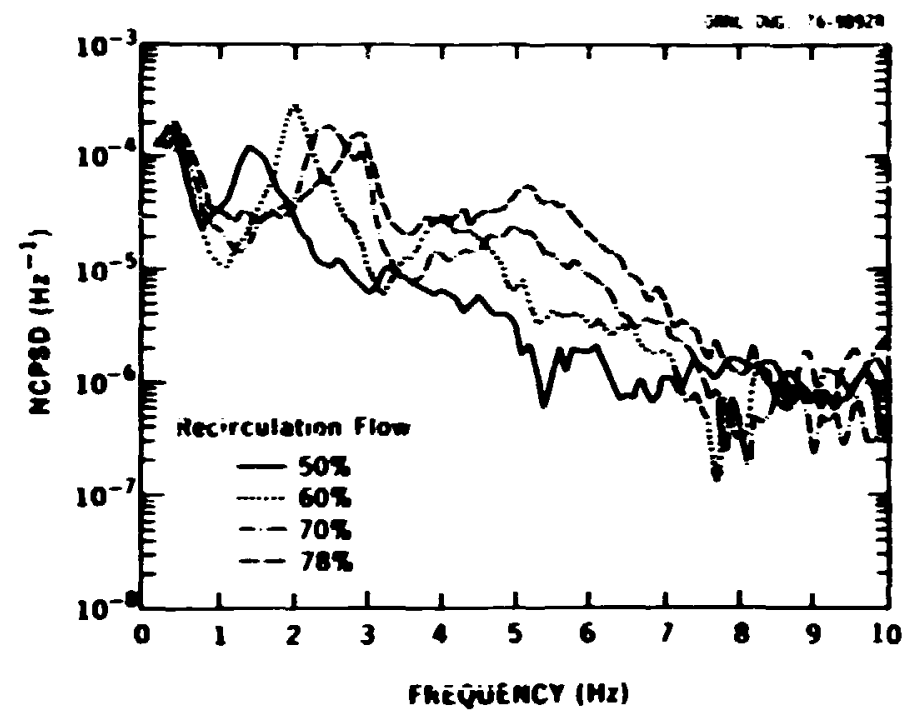

F18. 5. Flow dependence of RCPSD between C and D detectors.

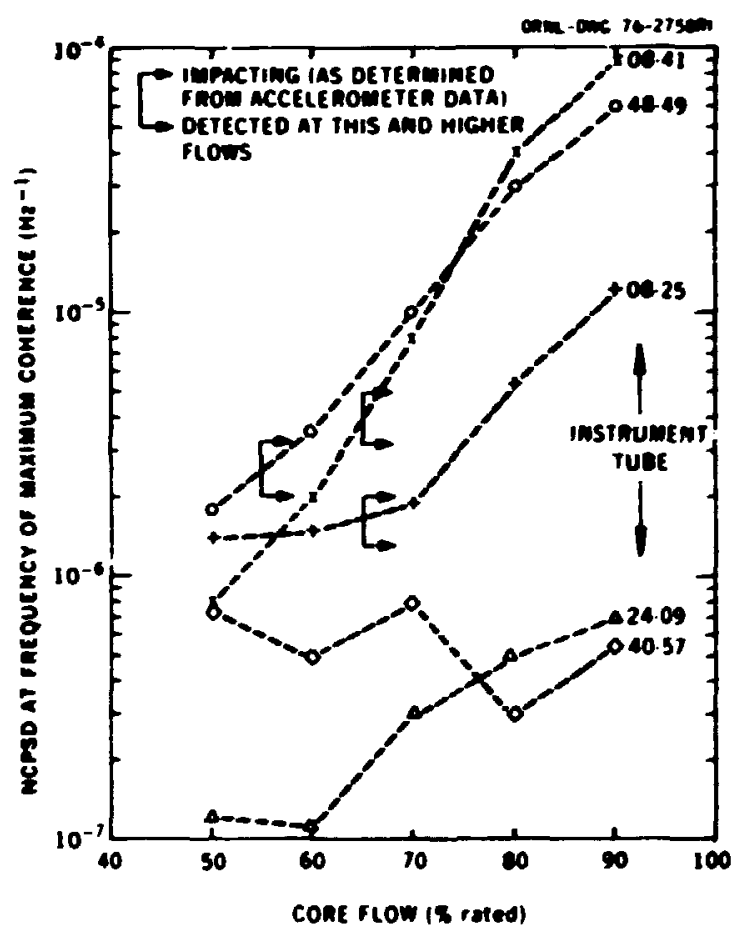

P18. 6. Comparison of 4-6 Hz NCPSD between C and D detectors with ex-vessel accelerometer results. 
ceasuresents in three 2R-4s to establish that the shape and absolute level of nonal background nolse are comon properties anong plants. In this comparison, care vas taken to select instruneat tubes that shoved no evidence of vibration or Ipacting; even so, some of the spectra Indicate sone slight evidence of vibration (2-3 Hz) at higher flous (see F18. 7). Wevertheless, the results in P18. 7 show that neutron noise signatures fron different BWR-4s are quite sinilar. We therefore conclude that the criterion described in the preceding paragraph for the neutron noise level that Indicates ifpacting can be applied to all BWR-4s.

\section{USE OF TIP TRACES POR IHPACT MOAITORIMG}

In addition to the fixed-posftion LPEA detectora, Ear-48 also have craversing in-core probes (IIP) that can travel continuously along the channel in a guide tube contained within the sane instrunent tube that houses the LPRY detectors. It has been suggested by Cheng ${ }^{3,4}$ that the amplitude of nolse superimposed on a IIP axial flux plot (comonly called

a TIP trace, F18. 8) has, in some cases, a significant correlation with channel box cormer wear.

However, we belleve that because the $x-y$ recorders used to plot IIP traces have a pour frequency response $(-3 \mathrm{~dB}$ at $<2 \mathrm{Bz})$ that varies greatly from plant to plant, IIP traces cannot be used as a rellable survetllance tool for instrunent tube ipacting, because the latter generateg 4-6 Hz neutron notse. In addition, IIP traces are often contaminated by low-frequency noise (unrelated to instrunent tube vibration) that is introduced by wold transport and normal flow and pressure fluctuations. By contrast, spectral analysis of the signals from LPRM or TIP 

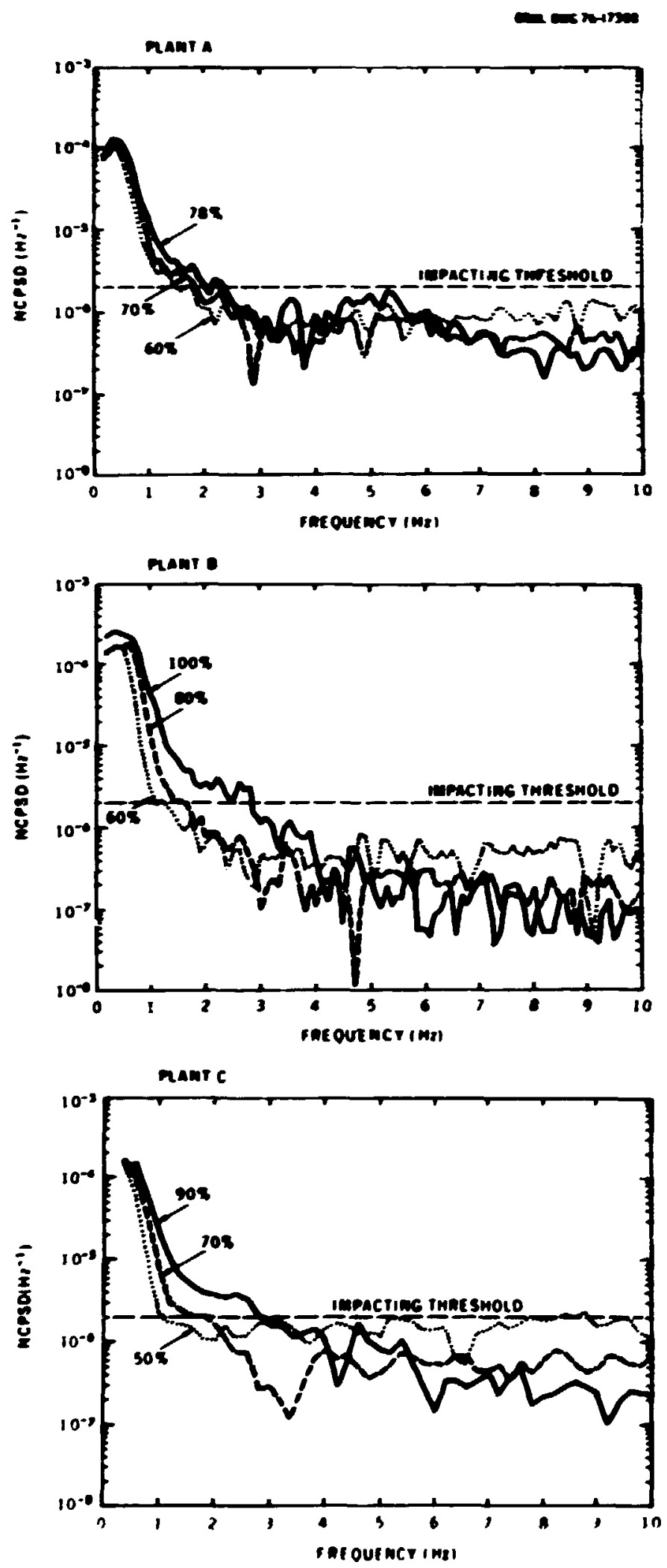

F18. 7. Typical MCPSD between $C$ and $D$ detectors ve flow for three anR-48. 
OAMR-DN: $76-17774$

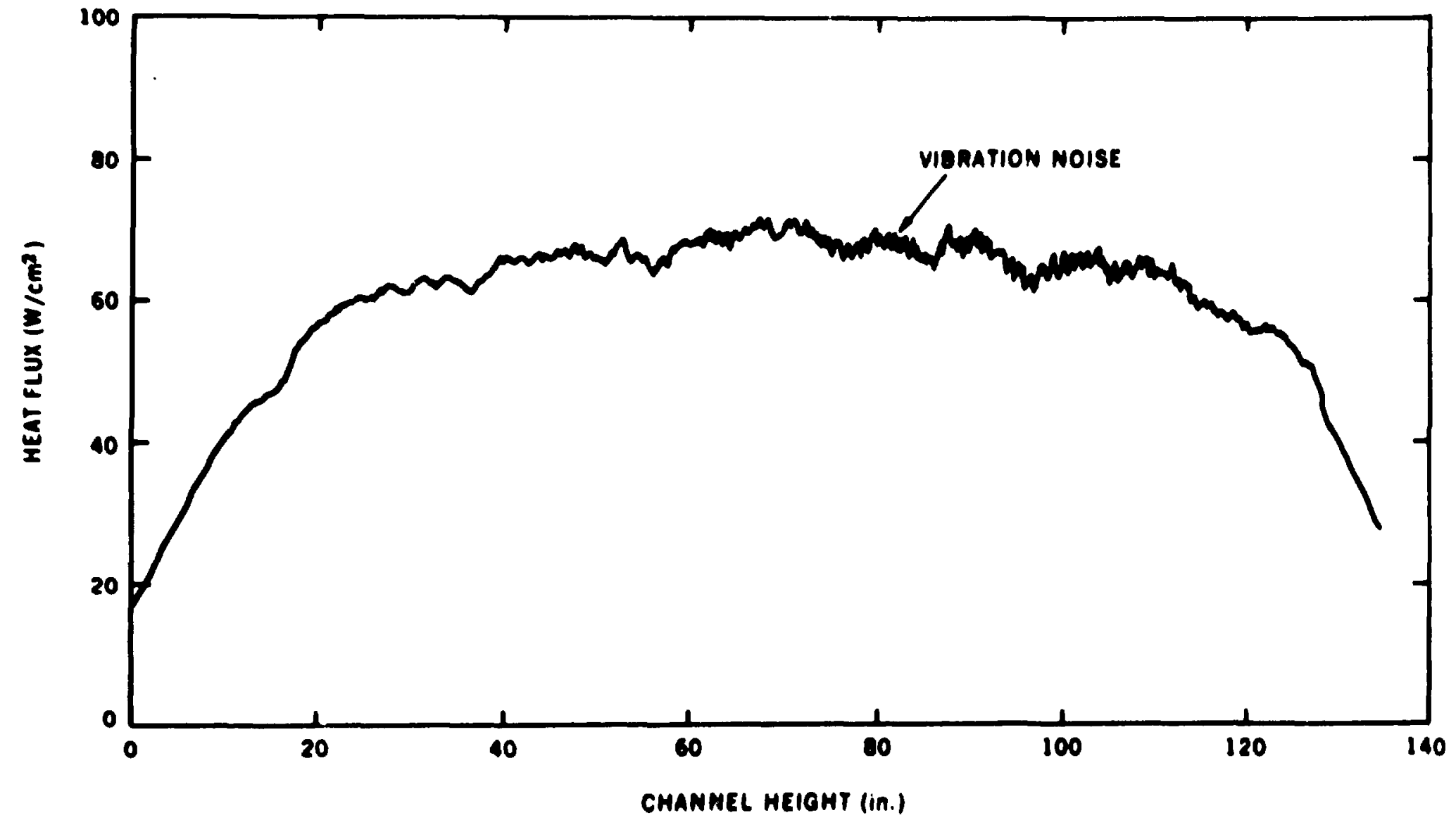

P18. 8. Typlcal axial flux plot (TIP trace). 
detectors allows 1solation of the noise directly related to Instrument tube vibration or flpacting.

\section{EFFECT OF BYPASS HOLE PLUGGING ON VIBRATIOAS}

Neutron noise analysis (NCPSD) was used to detenine the degree to which plugging of the bypass cooling holes in the core support plate elininated instrunent tube vibrat lons and inpacts. Heutron nolse measurewents were made at a $\mathrm{Bu}_{\mathrm{R}} 4$ plant before and after the coolant holes vere plugged. The RIPSD of the LPRA C and D detectors and the MCPSD between these detectors in each of 31 in-core detector strings were computed utilizing an on-line, ninicoputer-based noise analysis systea.

Figure 9 show spectr: obtalned at $\sim 807$ flow before and after plugging. Wote that the aplitude of the MCPSD in the 4- to 6-Hz range is below $2 \times 10^{-6} \mathrm{~Hz}^{-1}$ after plugsing. Furthernore, the coherence between $\mathrm{C}$ and $\mathrm{D}$ detectors is negligible in the 4- to 6-\#z range after plugging (FiB - 10). These coherence esourements support the conjecture presented in Sect. 3 that chanel box wotion caused by ipacting causes perturbations in the neutron flux which are coherent along the tube axis.

The neutron nolse signatures at $80 \%$ flon from all 31 LPEH strings after plugging are show with a typtcal signature obtained before plugging In Fig. 11. Sased on the criterion stated in Sect. 3 (MCPSD $<2 \times 10^{-6}$ $\mathrm{Hz}^{-1}$ ), we conclude that plugging the bypass coolant holes greatly reduces (and sost probably elininates) ipacting of instrunent tubes against channel boxes. Bowever, It should be reemphasized that these signatures were obtained at $280 \mathrm{z}$ of full rated flow (due to temporary plant power restrictions at the tire the measurements were sade). 


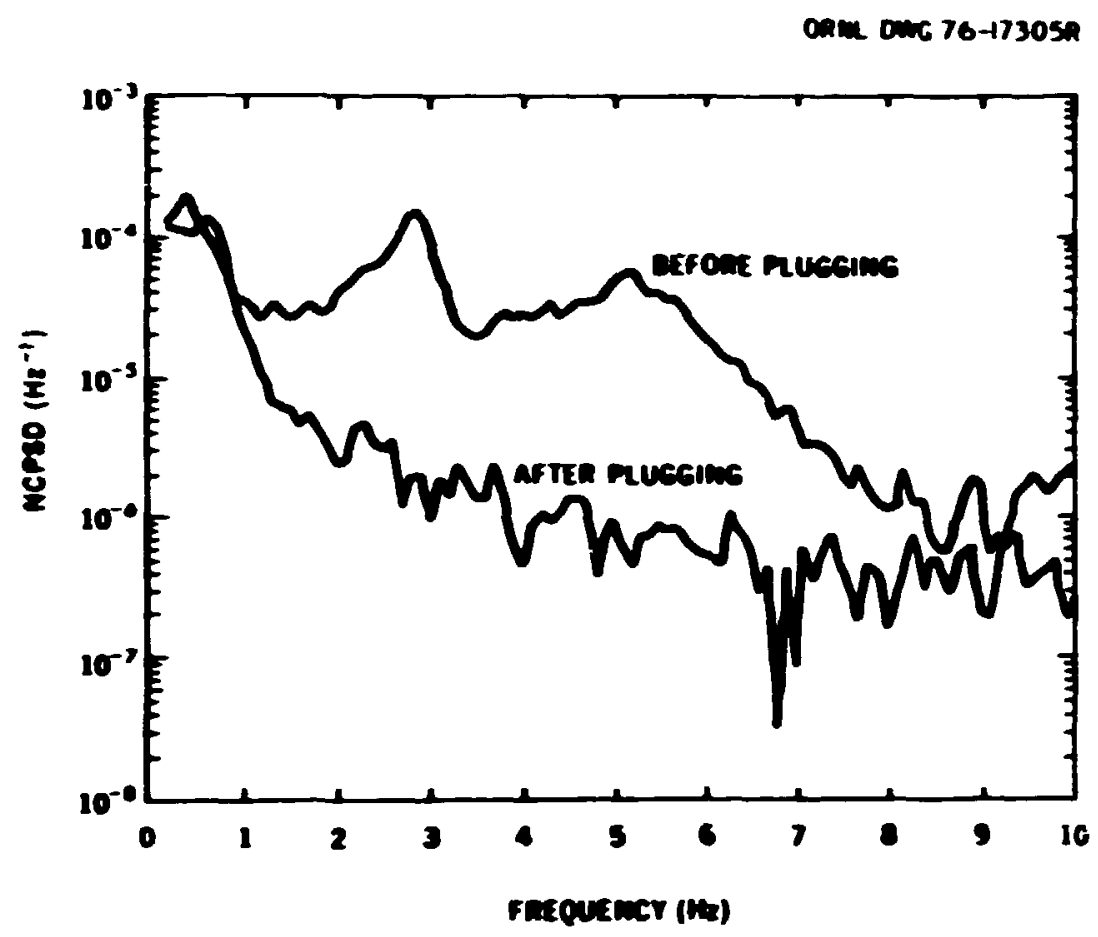

Fi8. 9. MCPSD between C and D detectors at $80 z$ flow before and after plugging.

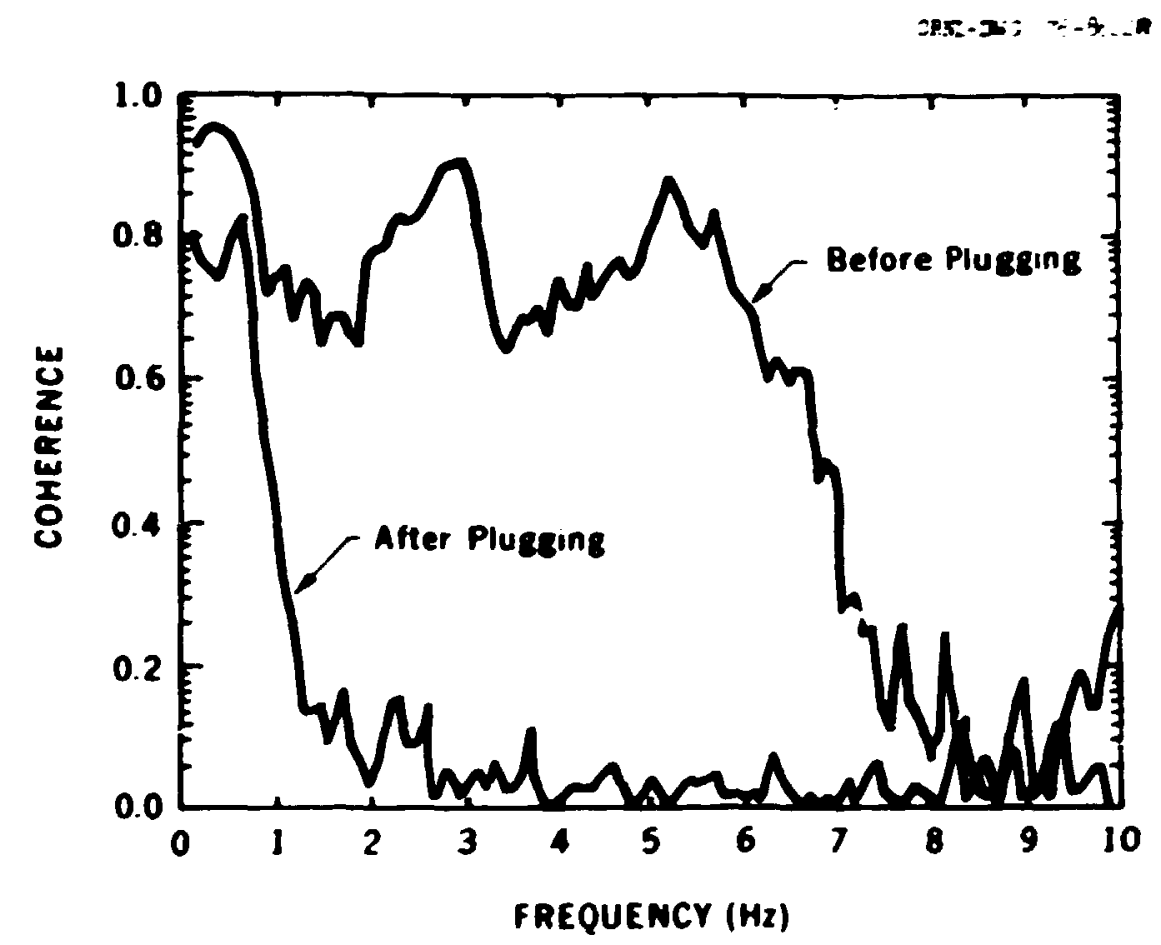

P18. 10. Coherence between $C$ and $D$ detectors at $80 \%$ flow before and after plugging. 


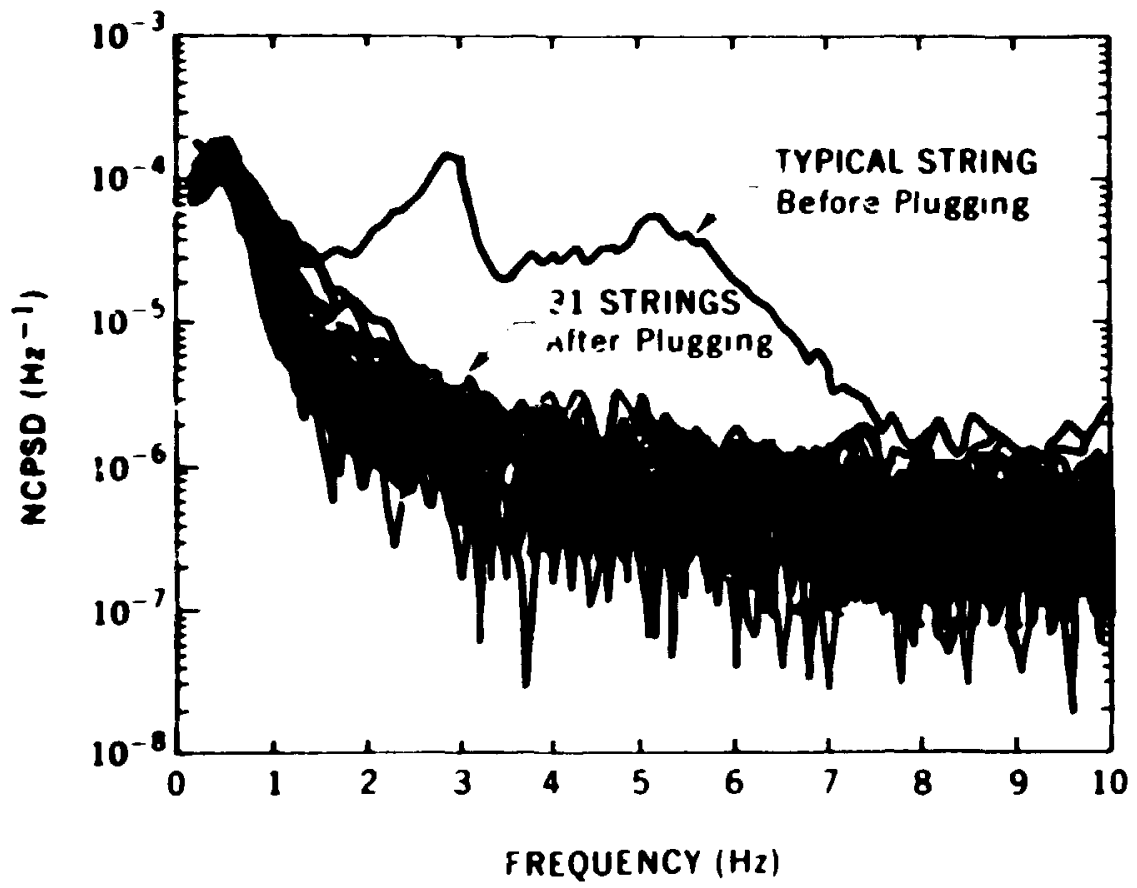

Fig. 11. Comparison of a typical impacting signature (C and D MCPSD) before plugging with signatures from 31 strings after bypass coollng holes were plugged. 
6. COMPARISON OF NOISE SIGMTURES

WITH VISU IL INSPECTION OF FUEL BOXES

Neutron noise signatures were compared with the results of visual Inspection of fuel channel boxes in three BWR-1,s. " Iu anking this comparison, we postulated that if the NCPSD between C and D detectors in the frequency range from 4 to $6 \mathrm{~Hz}$ is $>2 \times 10^{-6} \mathrm{~Hz}^{-1}$ the fuel boxes should show wear. We belfeve that damage of channel boxes is related to the cumlative impacti:ag and rubbing experienced by the boxes, whereas the noise signatures indicate only the conditions at the time of the measurement. Nevertheless, we attempted to compare the notse level in the 4- to 6-Hz frequency range with the nuber of fuel boxes refected based on visual inspection. The resilts are tabulated in Table 1.

The comarison of Table 1 has several 1 imftations: (1) the plant operat ing procedure at the time of noise measurements limited the core flow to less than $100 \%$ of full rated flow in some cases (In Sect. 3 we showed that Impacting diminishes as flow is reduced); (2) the NCPSD of all LPRH strings could not be obtained because some $C$ or $D$ detectors were out of service; (3) noise measurements vere not made imediately prior to shutdown for fuel box inspection (the the between measurements and Inspection was as great as 6 months in the case of ore plant).

Although the results are encouraging in that danaged boxes were found at locations where the NCPSD was $>2 \times 10^{-6}$, there were also damaged boxes at locations where neutron nofse analysis indicated no impacting at the time of measurement. One posstble explanation is that the damage

${ }^{\star} \mathrm{GE}$ and plant psrsonnel inspected the fuel boxes. 
Table 1. Visual InEpection of fuel boxes ve neutron notse level

\begin{tabular}{|c|c|c|c|c|c|c|c|c|c|c|}
\hline \multirow{2}{*}{ Plant } & \multirow{2}{*}{$\begin{array}{l}\text { No. of } \\
\text { LPRH } \\
\text { Stringa }\end{array}$} & \multirow{2}{*}{$\begin{array}{l}\text { No. of } \\
\text { LPRM } \\
\text { Stringe } a\end{array}$} & \multirow{2}{*}{$\begin{array}{c}\text { Tlma } \\
\text { Lapeeb } \\
\text { (monthe) }\end{array}$} & \multirow{2}{*}{$\begin{array}{c}\text { Core low } \\
\text { ( } 7 \text { of luil rated) }\end{array}$} & \multicolumn{3}{|c|}{$\begin{array}{l}\text { Number of LPRM } \\
\text { stringo Surrounded } \\
\text { By At Least One } \\
\text { Refected Channel Box } \\
\text { for HCPSD }\left(\mathrm{Hz}^{-1}\right) d\end{array}$} & \multicolumn{3}{|c|}{$\begin{array}{l}\text { Number of LPRM } \\
\text { stringe Surrounded } \\
\text { By No Refected } \\
\text { Channel Boxes for } \\
\text { NCPSD }\left(\mathrm{Hz}^{-1}\right)\end{array}$} \\
\hline & & & & & $<2 \times 10^{-6}$ & $>2$ & $\times 10^{-6}$ & $<2 \times 10^{-6}$ & $>2$, & $\times 10^{-6}$ \\
\hline $\mathbf{A}$ & 31 & 31 & 0.5 & 80 & 2 & & 23 & 3 & & 3 \\
\hline B & 43 & 33 & 5 & 90 & 6 & & 21 & 5 & & 1 \\
\hline c & 43 & 39 & 6 & 80 & 7 & & 16 & 12 & & 4 \\
\hline C & 43 & 33 & 6 & 100 & 1 & & 21 & 6 & & 5 \\
\hline
\end{tabular}

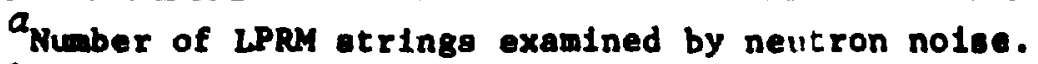

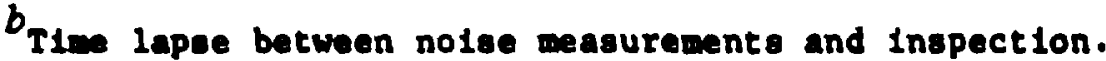

Core flow at the of nolee measurement.

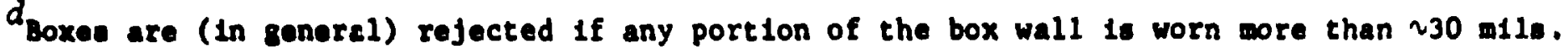


night have occurred prior to the nolse measurements, but, orlng to channel box vear, the vibrating instrusent tube no longer contacted the fuel box at the time the neutron noise measurements were made. Dange wy also have occurred between the tine of noise masurenent and shutdorn for inspecticn. It is surnised that periodic wolse moitoring from plant startup to shutdown aight have detected impacting during some interval. As expected, the results indicate in the case of Plant $C$ that nolse neasurenents at full flow are a core reliable indicator of wear then measurements at 802 of full flow.

Table 1 also show the converse situntion, 1.e., sone IPWH strings had no rejects around then, but there was a definice indication of inpactIng based on the MCPSD. However, "no rejects" does not inply zero box wear, because the inspection criteria for re-use allows a slight mount of wear.

Altbough these results are, In general, encouragins, we believe it Is presature to conclude positively that neutron noise analgsis can be used to predict wear of chmonel boxes.

\section{7. comcrustous AND recomemarious}

We conclude that: (1) acceleroneters wounted on the instrunent guide tube extension outside the reactor vessel can be used to detect Imacting, but not rubbing, of that (and only that) Instrument tube against surrounding fuel channel boxes; (2) 4- to 6-tz neutron noise from the $C$ and D IPRY detectors can 11kewise be used to detect impacting at any core location having a string of LPRY detectors; (3) plugging of the bypass cooling holes greatly reduces instrument tube vibration and 
elininates ifpacting for core flow rates of 0-80z of full rated flow (ceasurements could not be obtained at higher flow rates); (4) neutron noise signatures obtained at a single time prior to shutdown are not a reliable replacement for visual deraminarioa of cunlative channel box dange caused by lpacting by instrunent tubes; and (5) the noise on TIP traces obtained with standard plant instrunentation is not a rellable indicator of ipacting.

We recomend that: (1) a combination of accelerometers and LPRM signals would provide the best ethod for in-service wonttoring for ipacts (acceleroneters would be used to wontor those instrinent tubes containIng intermediat $2-$ range woitcrs, source-range wonitors, and sourses); (2) If sone Impacting still occurs after BUR-4 cooling hole wodifications, then additional studies should be conducted to deternine if neutron or acceleroneter noise wontoring performed periodically during a fuel cycle can be used to predict the degree of channel box damage; (3) a calculational methodology should be developed for calculating the response of in-core neution detectors to flux perturtations caused by such wovenents as instrument tube vibrations, channel flow perturbations, and control rod perturbations; and (4) mechanical calculations should be ande to deternine if rubbing excites the 4- to 6-Hz channel box resonance, and, If it does, the relative anplitude of neutron noise seen by in-core detectors should be deternined. 


\section{REFERENCES}

1. N. J. Ackerann, Jr., et al., "Dlagnosis of In-Core Instrunent Tube Vibrations in Bur-4s," Trans. Aner. Rucl. Soc. 22,624 (1975).

2. D. N. Fry, R. C. Kryter, and J. C. Robinson, "Analysis of MeutronDensity Oscillations Resulting from Core Barrel Hotion in the Palisades Muclear Power Plent," Annals of thel. Energy 2., 341-351 (1975).

3. H. S. Cheng and D. J. DHamond, "A Neutronic Correlation of DAR IIP Noise," Trans. Amer. Hucl. Soc. 23, 469 (1976).

4. H. S. Cheng, A Study of the Effect of Position and Voids on BUR Incrre Detector Readings, Brl-20547 (September 1975). 